\title{
Examining the changes in car ownership levels in the Greater Dublin Area between 2006 and 2011
}

\begin{abstract}
The aim of this study was to examine the changing nature of car ownership in the Greater Dublin Area (GDA) and to determine the characteristics of households most likely to have changed their car ownership levels between 2006 and 2011. The analysis was carried out using the census data from 2006 and 2011. A multinomial logistic regression model in tandem with geographic information system (GIS) visualisation was used to examine the impact of a set of individual, household and transport characteristics on average car ownership levels. The findings demonstrate that the age of individuals, the year their household was constructed, residential density and the mode of travel to work had an impact on the change in car ownership levels over the study period. Rail availability had significant influence where there was a decrease in average car ownership levels. However, the impact of bus transport on car ownership levels was less apparent. The study was set against the background of the worst economic recession in the history of the Irish state and the impact this had on the findings cannot be ignored. Nonetheless, by identifying households likely to have changed their car ownership over the study period the findings may assist policymakers in the future as they attempt to create transport initiatives which will encourage more sustainable travel modes.
\end{abstract}

\section{Introduction and Background}

This paper examines changes in average household car ownership levels in the GDA between 2006 and 2011. A multinomial logistic regression model was then used to ascertain the specific characteristics of individuals living in areas with changes in car ownership levels. The time period of the study is particularly interesting as it encompasses the height of the economic boom in Ireland, the subsequent recession and beginnings of a possible recovery. It is hoped that the findings will offer a useful insight to decision makers, transport planners and automobile manufacturers as they give an indication of the demographics of people likely to change their car ownership patterns over a period of time. However, recent research has shown that the recession has increased the use of unsustainable transport modes due to housing in areas with poor access to public transport (Caulfield and Ahern, 2014).

Up until the early 1990's Ireland had one of the lowest levels of car ownership in the European Union (EU). The economic boom, in the 1990's, led to a huge increase in car ownership and brought levels on par with our European counterparts (National Transport Authority, 2012). This increase in car ownership has been a worldwide trend over the past two decades (Pongthanaisawan and Sorapipatana, 2010). Economic prosperity and attractive bank lending rates available during the period 2001-06 contributed to this increase in car ownership levels in Ireland (Morgenroth, 2002). In Ireland, the number of private vehicles grew by $28 \%$ during the period $2001-06$ (CSO, 2012a). Presumably as a result of the economic recession the number of private vehicles in Ireland fell in 2009, as can be seen in Figure 1. There has also been a reduction in new private vehicle registrations since 2007 (Figure 2). This reflects the ageing nature of the private vehicle stock in Ireland. Despite this, in 2011, 1.36 million households had access to at least one car which is an increase of 186,000 (16\%) on 2006 (CSO, 2012a). Besides affecting car ownership, the economic recession also impacted upon the workforce. In the context 
of this study it is important to note that within the state the number of workers fell by $6 \%$ from $1,892,787$ to $1,778,400$ over the study period (CSO, 2012b). Hennessy and Toll (2011) using more recent data predicted that there would be 2.4 million vehicles in Ireland by 2025 . This forecast suggests there will be a reduction in the growth of car ownership levels witnessed during the 'Celtic Tiger' era.

The results presented in this paper build upon those presented in Caulfield (2012) in demonstrating how car ownership levels are changing in the region. The research presented in this paper builds on this work and shows how car ownership levels in the GDA have begun to increase again as shown in the increasing numbers of newly registered cars in 2012 and 2013 in Figure 2.

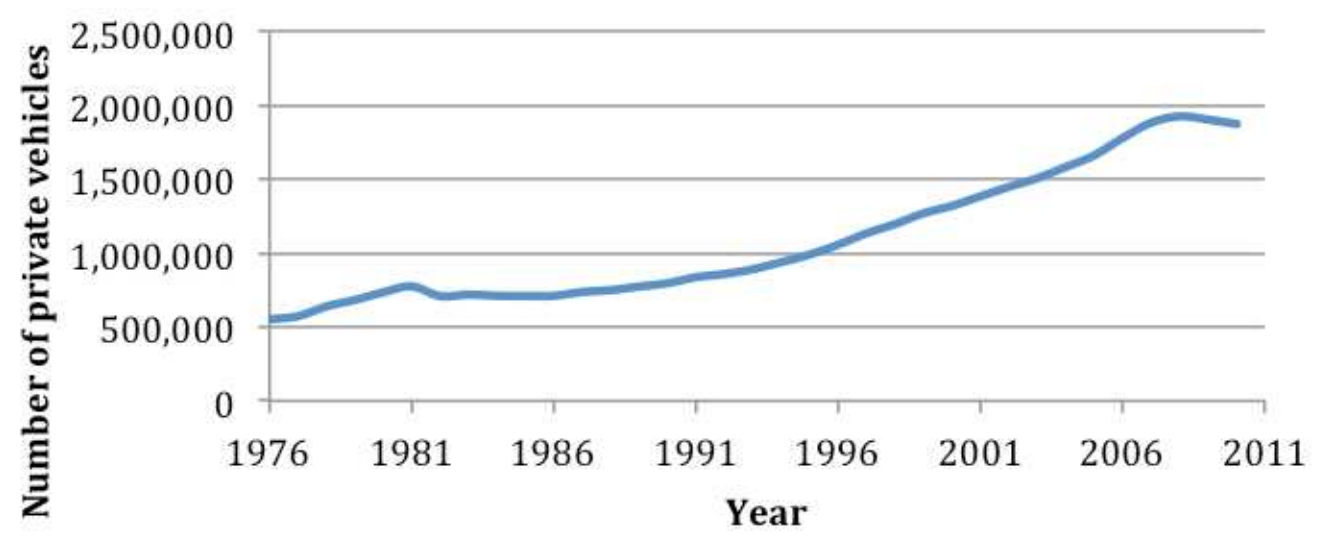

Figure 1 Growth in car ownership levels 1976-2010 (CSO, 2011)

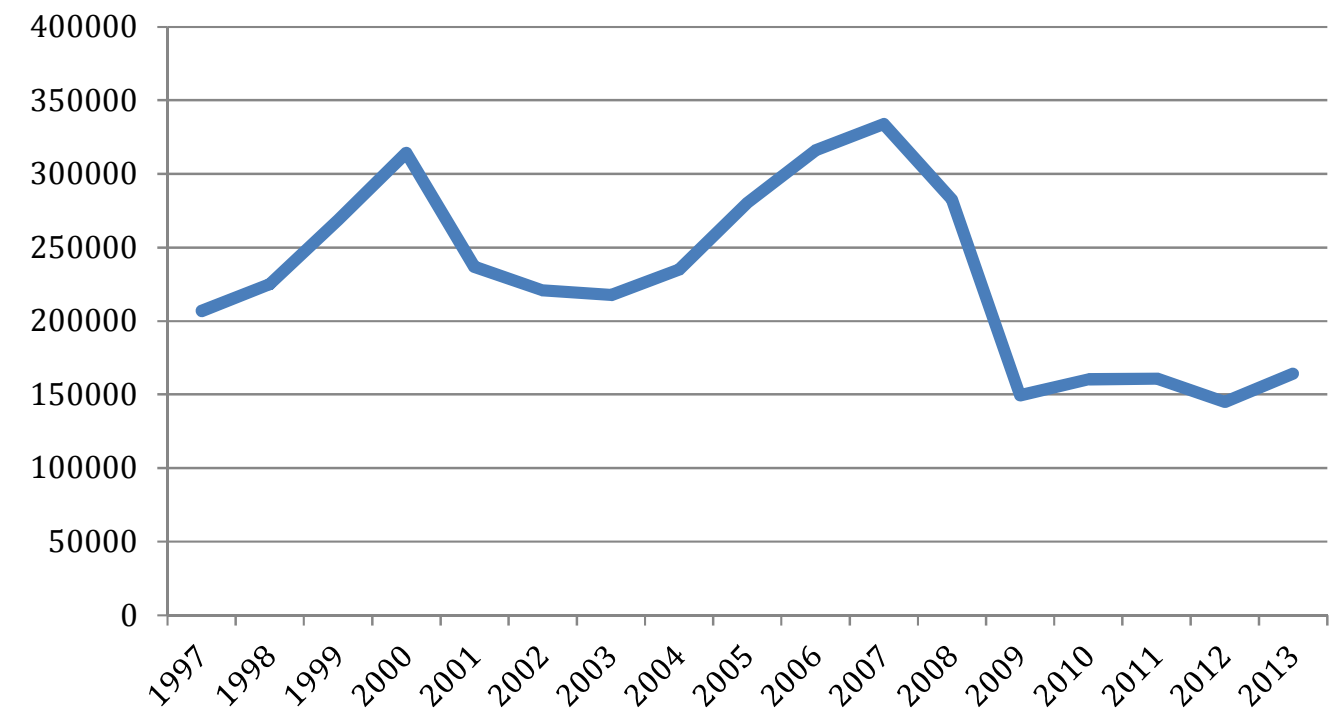

Figure 2 Newly registered vehicles 1997-2013 (CSO, 2014)

The trend in increasing car ownership in Ireland can be clearly seen when examining the mode of travel to work over the last 25 years. Figure 3 highlights this relationship 
and the dominance of driving to work since 1986. The number of people traveling to work by car, in Ireland, has been progressively increasing and in 2011 accounted for $69 \%$ of trips. The percentage of people traveling to work on foot and by bicycle has decreased since 1986. Over the same period the percentage of people traveling by train has increased $(2 \%)$ while those travelling by bus has decreased $(4 \%)$. However in recent years there has been a rebound in the use of cycling in Dublin and significant increases in this mode of transport have occurred in Dublin (Caulfield, 2014). In 2011, public transport accounted for only $8 \%$ of the total journeys to work. The increase in car ownership has also had a major impact on the number of children traveling by car to school: increasing from 19\% in 1986 to $49 \%$ in 2011 (CSO, 2011).

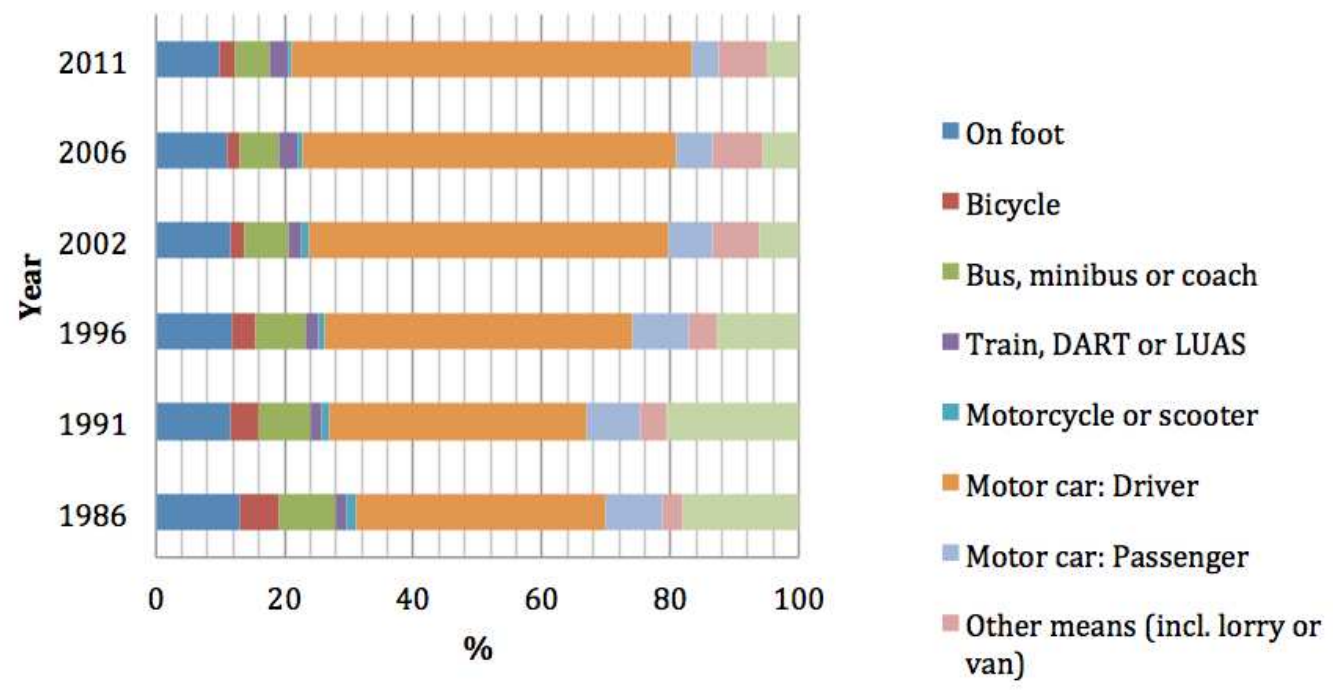

Figure 3 Mode of travel to work 1986-2011

The GDA encompasses Dublin city and county together with counties Wicklow, Kildare and Meath. The GDA is situated on the east coast of the island. According to the Central Statistics Office (CSO) the population of the GDA in 2011 was 1,804,156 which equates to $39.3 \%$ of the total population of the Republic of Ireland. This region has experienced a 34\% growth in population since 1991. Dublin city is a low density city with widespread urban sprawl occurring in the GDA region. Employment is concentrated in the city centre and the inner and outer suburbs of the city (National Transport Authority, 2007).

The main objective of this study was to determine what factors have impacted upon the change in household car ownership in the GDA. The study set out to compare average household car ownership levels in 2011 to those of 2006. The study will give a greater understanding to transport planners and decisions makers with regards to the effects of transport initiatives on household car ownership.

\section{Literature Review}

A considerable amount of research has been conducted to examine the determinants of car ownership worldwide. These have focused on predictions based on (1) demographic characteristics, (2) socio economic characteristics and (3) transport characteristics. Clark (2009) used a relatively new technique of rough sets analysis to identify the determinants which influence car ownership in a household. Using the 
British National Travel Survey, the study found that income; number of residents and household composition are all significant factors in determining household car ownership. Using a multinomial logit model, Bhat (2007) considered the effects of a range of variables on the car ownership in the San Francisco Bay area. This study found a high propensity to car ownership if the commute time is long and a low propensity if the cost of the commute is high. Giuliano and Dargay (2006) proposed that the rise in car ownership as a function of per capita income is because time is more valuable.

Several studies have combined datasets to estimate and predict car ownership levels. Whealan (2007) used a combination of the National Travel Survey, a family expenditure survey and census data to examine car ownership in the UK. The idea that car ownership can reach saturation levels was also examined in this study. It found that less densely populated areas and households with three or more adults have the highest saturation levels. It predicted that car ownership will increase across the UK until saturation levels are reached. Car saturation was also the focus of a study by Delbosc (2013) which revealed that large households are less likely to saturate than small households. This can be explained by the greater opportunities to car pool which are available in households with more adults. Dargay and Gately (1999) using data compiled between 1960 and 1992 forecasted that in Ireland the ratio of cars to population in 2015 would be 0.52 . This approximates to 2.1 million cars. This relied on an economic model based on car/population ratio as a function of per-capita income. It assumed economic growth per capita would continue into the future. However, the accuracy of their forecast is questionable given the economic boom the country experienced between 2002 and 2008 and the depth of the subsequent recession.

The research presented in this paper examines the impacts that access to public transport has on car ownership levels. Several other authors have also examined how public transpor access impacts on car ownerhsip. A disaggregate choice model based on a questionnaire of Taiwanese car owners revealed the impact of transport on car ownership (Chiou et al. 2009). Taiwan is a city with a high car dependency. The study suggested that cities with convenient public transport may reduce the dependency of residents on the private car. Kim and Kim (2004) using an ordered logit model also found that access to public transport in the United States of America (USA) had a large negative impact on the number of cars owned. Further research in Ireland by Nutley (2005) identified that the period of rapid car ownership growth in Northern Ireland (1979-2001) coincided with increased journey lengths to urban centres and reduced public transport use.

Several studies have looked at trends in car ownershop levels. Ritter and Vance (2013) predicted that car ownership will rise in Germany until 2030 despite a reduction in the population. While the average age of the Irish population will have increased considerably by 2025 (Forfás Ireland, 2009) this may not result in a decrease in car ownership levels here. In the United Kingdom (UK), Whelan (2007) has predicted that by 2031 there will be a $16 \%$ increase in the number of households with two cars and a $39 \%$ increase in households with three or more cars.

This literature review has examined car ownership under a number of different headings at it was found that key factors which impact upon it include; income, household composition and public transport availability. However, there remains a paucity of data on the characteristics of households in areas which have seen a change in average car ownership levels over a period of time. Furthermore a comparison of 
car ownership levels between the main urban centres in Ireland has not been undertaken.

\section{Methodology and data}

\subsection{Data used}

The data used in this study was taken from the 2006 and 2011 census of the Irish population. The census is conducted every five years by the Central Statistics Office (CSO) and includes all individuals present in the country on that particular date. The data used in this study was taken on the nights of Sunday, $23^{\text {rd }}$ April 2006 and Sunday, $10^{\text {th }}$ April 2011. From this data an anonymised set of records called the Place of Work Census of Anonymised Records (POWSCAR) is compiled. POWSCAR 2006 details the journeys to work of individuals aged 15 years of age or over, while POWSCAR 2011 includes information on individual's journeys to work, school and college.

Within the POWSCAR dataset different personal, household and travel characteristic variables are defined for each entry. These include age, gender, highest level of education completed to date, socio-economic group, household composition, year household was built, residential area type, mode of travel to work, school or college, time of departure to work, school or college, journey time to work, school or college, number of cars or vans available for use in the household, location of usual residence and location of place of work, school or college. Respondents are responsible for reporting on the variables in the census. Unfortunately data on income is not available.

\subsection{Model formulation}

The number of workers and the number of cars in each of these workers households was extracted from the dataset. This information was then used as an approximation for the average car ownership per household in each electoral division (ED) as per Equation 1. The values for 2006 and 2011 were then compared for each ED to determine if an increase, decrease or no change in the average car ownership per household was experienced. A new variable was then created in the 2011 dataset to illustrate this finding. The increase or decrease was given as a percentage of the average car ownership level per household in 2006. No change in car ownership was defined as having a value between $-1 \%$ and $1 \%$.

\section{Equation 1}

Average household car ownership $=\frac{\text { total number of cars available to workers in ED }}{\text { total number of workers in ED }}$

To enhance the understanding of the average household car ownership in the GDA, the data was mapped using ArcGIS. Maps were produced for the GDA to represent; average car ownership level in 2006, average car ownership level in 2011 and the change in average car ownership between 2006 and 2011.

A multinomial logistic regression model was used in this research to determine the factors which have influenced the change in average car ownership level per household between 2006 and 2011. Multinomial logistic regression is a form of multiple regression in which a number of predictors are used to calculate 
values of a single nominal dependent variable. The dependent variable used in this model was the change in average car ownership level per household for each ED. The dataset was segmented into three groups: EDs which have shown an 'increase' in average car ownership levels, EDs which have shown a 'decrease' in average car ownership levels and EDs which have shown 'no change' in average car ownership levels. The objective of the regression modelling is to find the predictor variables which identify the category which an individual is most likely to be a member of. In doing so it also effectively identifies the variables which are not effective in distinguishing between different categories of the dependent variable.

The model analyses the relationship between individual, household and transport characteristics and the probability of being from a particular region. The logit is used to predict category membership. The model used takes the form of equation 2:

\section{Equation 2}

$\operatorname{logit}(\pi)=\log _{e} \frac{\pi}{1-\pi}=a+\beta I+\delta H+\gamma T+e$

Where:

$\pi$ - probability that event $\mathrm{Y}$ occurs (person lives in an area with an increase/decrease/no change in average household car ownership level)

a- intercept value,

$\beta I$ - set of individual specific characteristics,

$\delta \mathrm{H}$ - set of household specific characteristics

$\gamma \mathrm{T}$ - set of transport specific characteristics

e - random error term (ignored as it is not used for making predictions)

Table 1 Description of variables examined

\begin{tabular}{|c|c|c|}
\hline Variable & & Definition \\
\hline Age & $15-24$ & $=1$ if age $15-24$ \\
\hline & $25-34$ & $=1$ if age $25-34$ \\
\hline & $35-44$ & $=1$ if age $35-44$ \\
\hline & $45-54$ & $=1$ if age $45-54$ \\
\hline & $55+$ & (Reference category = age 55+) \\
\hline Area type & $\begin{array}{l}\text { Urban area of } 0-999 \\
\text { people }\end{array}$ & $=1$ if: Urban area of $0-999$ people \\
\hline & $\begin{array}{l}\text { Urban area of } 1,000- \\
1,499 \text { people }\end{array}$ & $\begin{array}{l}=1 \text { if: Urban area of } 1,000-1,499 \\
\text { people }\end{array}$ \\
\hline & $\begin{array}{l}\text { Urban area of } 1,500- \\
1,999 \text { people }\end{array}$ & $\begin{array}{l}=1 \text { if: Urban area of 1,500-1,999 } \\
\text { people }\end{array}$ \\
\hline & $\begin{array}{l}\text { Urban area of } 2,000- \\
4,999 \text { people }\end{array}$ & $\begin{array}{l}=1 \text { if: Urban area of } 2,000-4,999 \\
\text { people }\end{array}$ \\
\hline & $\begin{array}{l}\text { Urban area of } 5,000- \\
9,999 \text { people }\end{array}$ & $\begin{array}{l}=1 \text { if: Urban area of } 5,000-9,999 \\
\text { people }\end{array}$ \\
\hline & $\begin{array}{l}\text { Urban area of } 10,000- \\
19,999 \text { people }\end{array}$ & $\begin{array}{l}=1 \text { if: Urban area of } 10,000-19,999 \\
\text { people }\end{array}$ \\
\hline & $\begin{array}{l}\text { Urban area of } 20,000- \\
49,999 \text { people }\end{array}$ & $\begin{array}{l}=1 \text { if: Urban area of } 20,000-49,999 \\
\text { people }\end{array}$ \\
\hline & Urban area of $1,000,000$ & (Reference category = Urban area of \\
\hline
\end{tabular}




\begin{tabular}{|c|c|c|}
\hline & people or more & $1,000,000$ people or more) \\
\hline \multirow[t]{10}{*}{ Year dwelling built } & Not stated & $=1$ if: Not stated \\
\hline & Before 1919 & $=1$ if: Before 1919 \\
\hline & $1919-1945$ & $=1$ if: $1919-1945$ \\
\hline & $1946-1960$ & $=1$ if: $1946-1960$ \\
\hline & $1961-1970$ & $=1$ if: $1961-1970$ \\
\hline & $1971-1980$ & $=1$ if: $1971-1980$ \\
\hline & $1981-1990$ & $=1$ if: $1981-1990$ \\
\hline & $1991-2000$ & $=1$ if: $1991-2000$ \\
\hline & $2001-2005$ & $=1$ if: $2001-2005$ \\
\hline & 2006 or later & (Reference category $=2006$ or later) \\
\hline \multirow{7}{*}{$\begin{array}{l}\text { Mode of travel to } \\
\text { work }\end{array}$} & Walk/Cycle & $=1$ if $\mathrm{walk} / \mathrm{cycle}$ \\
\hline & Bus & $=1$ if bus \\
\hline & Train & $=1$ if train \\
\hline & Car-driver & $=1$ if car - driver \\
\hline & Car-passenger & $=1$ if car - passenger \\
\hline & Other means & $=1$ if other means of travel \\
\hline & $\begin{array}{l}\text { Work mainly at or from } \\
\text { home }\end{array}$ & (Reference category = work from home) \\
\hline \multirow{6}{*}{$\begin{array}{l}\text { Bus stops per } 1000 \\
\text { people }\end{array}$} & None & $=1$ if none \\
\hline & $1-5$ bus stops & $=1$ if $1-5$ bus stops \\
\hline & $6-10$ bus stops & $=1$ if $6-10$ bus stops \\
\hline & $11-15$ bus stops & $=1$ if $11-15$ bus stops if none \\
\hline & $16-20$ bus stops & $=1$ if $16-20$ bus stops \\
\hline & $21+$ bus stops & (Reference category $=21+$ bus stops) \\
\hline \multirow[t]{2}{*}{ Rail availability } & No & $=1$ if $\mathrm{no}$ \\
\hline & Yes & (Reference category = yes) \\
\hline
\end{tabular}

\section{The change in car ownweship in the GDA between 2006-2011}

Figure 4 maps the average car ownership level per household for each ED GDA in 2006. The sub map presented focuses on the Dublin metropolitan area with the surrounding areas consisting of the counties Meath, Kildare and Wicklow. It can be seen that the areas with 2 or more cars per household are mainly located in rural parts of Meath, Kildare and Wicklow. Indeed, urban areas within these counties have lower average car ownership levels compared to their rural hinterlands. The lowest average car ownership levels per household are located in Dublin city centre and immediate surrounding areas. Generally the level of household car ownership increases the greater the distance from the city centre. 


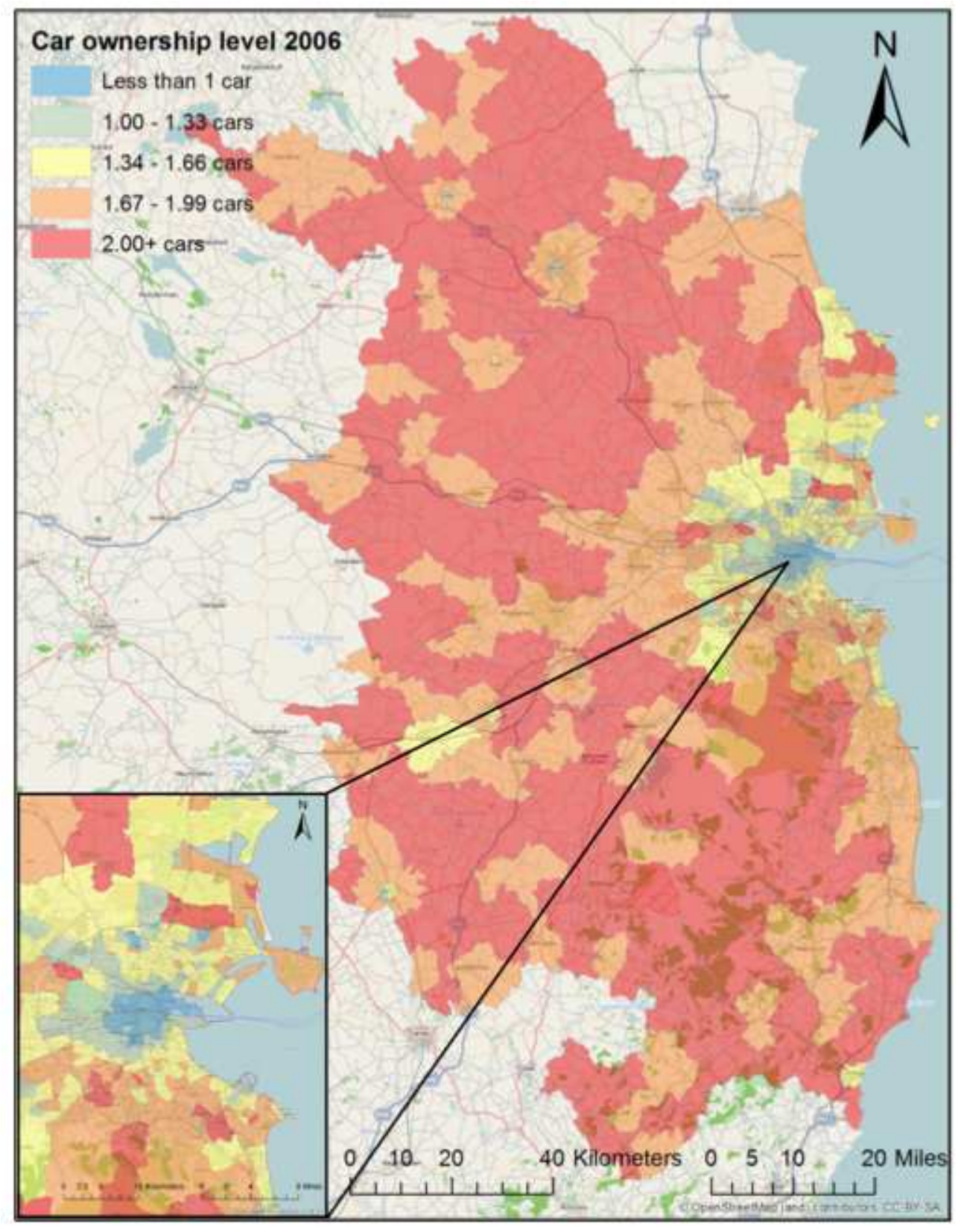

Figure 4 GDA average car ownership level per household 2006

Similar patterns of car ownership levels were evident in the 2011 census (Figure 5). Again the counties of Meath, Kildare and Wicklow have the majority of EDs where average car ownership levels are greater than two per household. Dublin city centre has the lowest levels of car ownership with levels increasing progressively moving out from the city centre. The regions identified in north west county Dublin in 2006 still have car ownership levels greater than two. As in 2006 the ED with the lowest car ownership level is the North City (0.22 cars per household). 


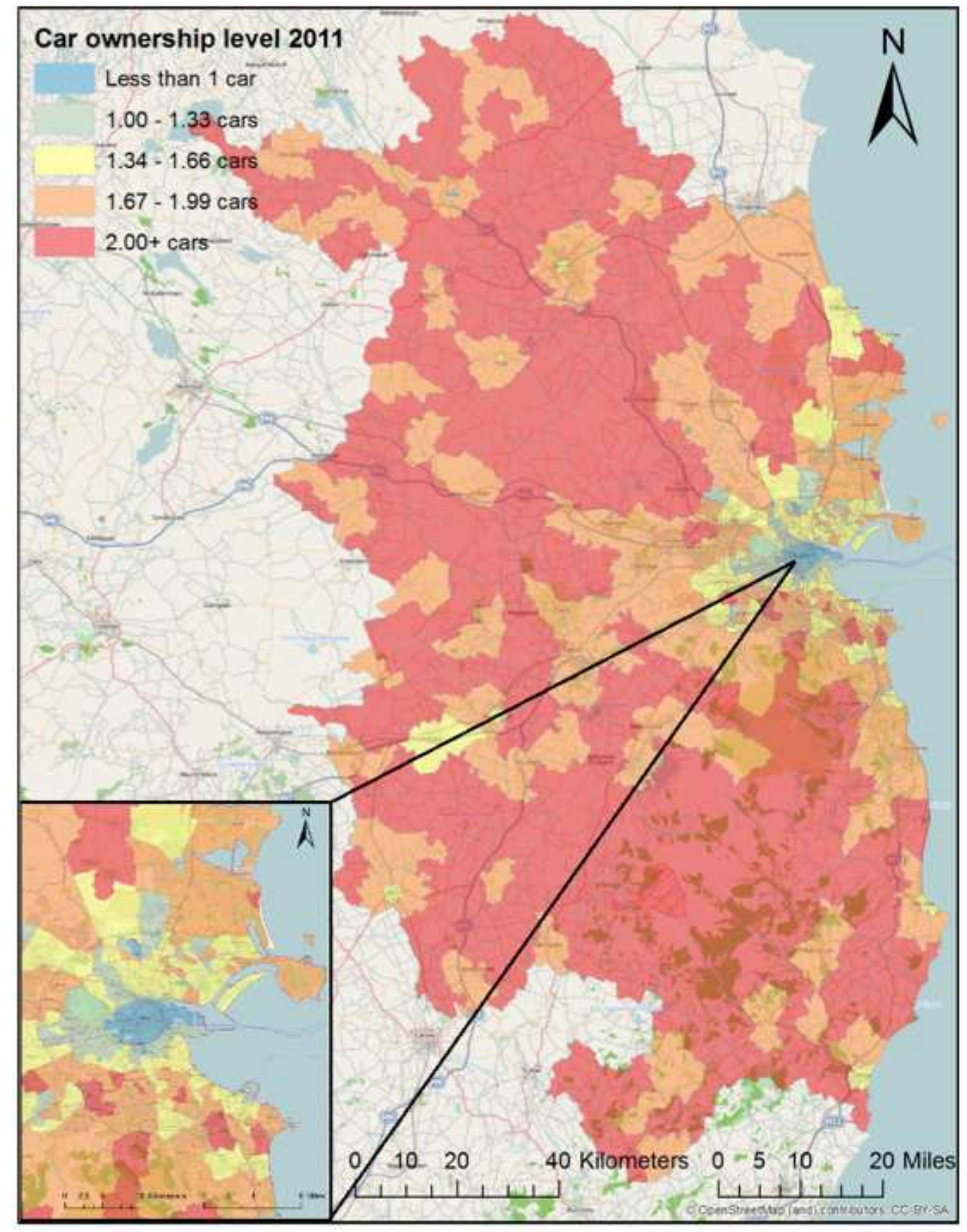

Figure 5 GDA average car ownership level per household 2011

Average car ownership levels have changed by more than $1 \%$ between 2006 and 2011 in the many of the EDs in the region (Figure 6). Many rural areas experienced a decrease in average car ownership levels. Focusing on Dublin city there has been a decrease in car ownership levels in the Docklands as well as some other parts of the inner city. In the inner suburbs, however, there has been a large increase, particularly south of the river Liffey. In western areas of the city situated within the boundary of the M50 motorway (Ring road around Dublin City) the level of car ownership has increased, but by different margins, $1-8.9 \%$ compared to $9-36.1 \%$. 


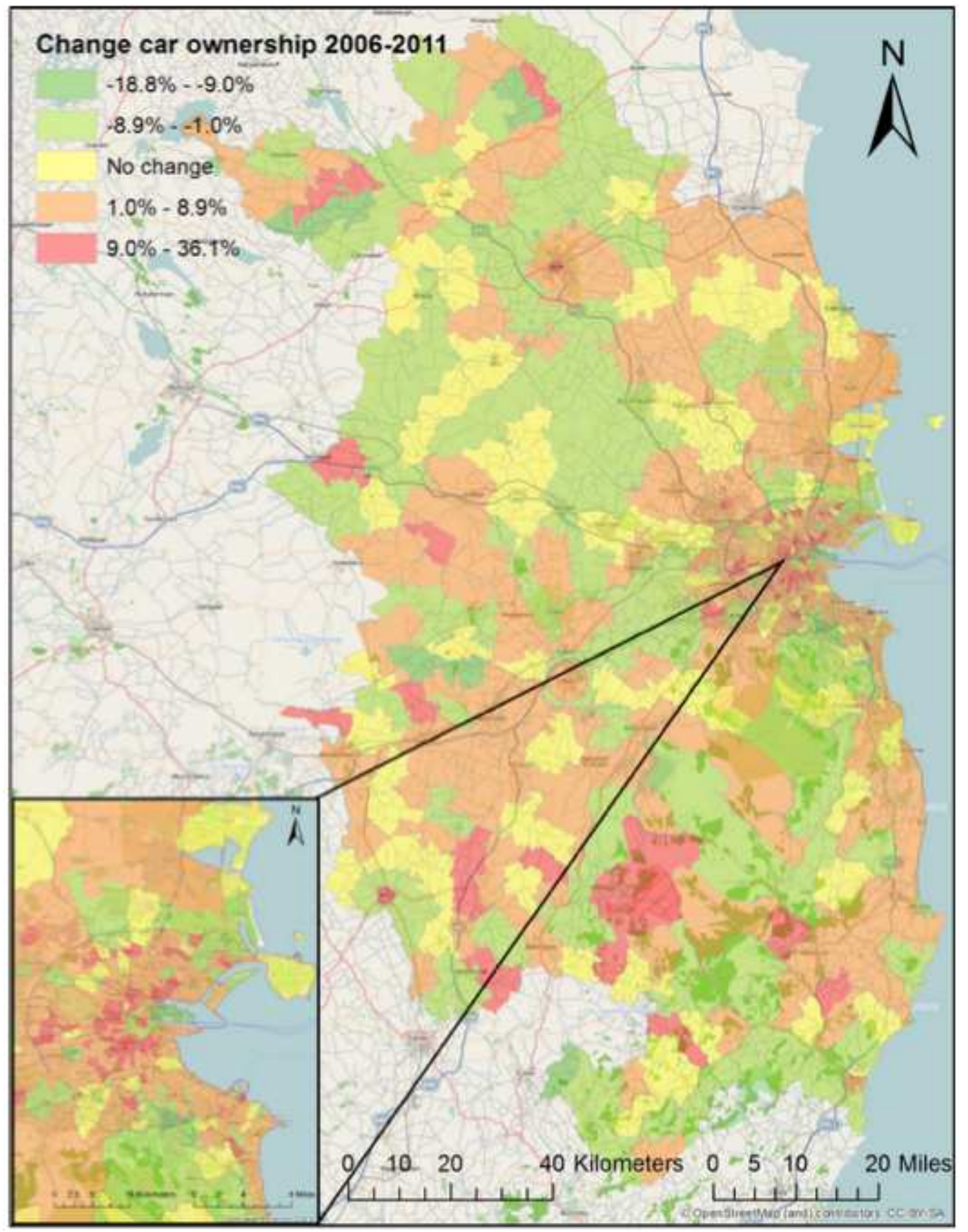

Figure 6 GDA change in average car ownership level 2006-2011

Table 2 contains descriptive statistics of the working population of the GDA and a description of the variables examined in the regression modelling. The first column presents the average figures for workers in this region; the other three are segmented by changes in the average car ownership level per household (increase, decrease, no change). The figures illustrate that in areas where there has been a decrease in average car ownership, 35\% of residents are aged 25-34. The second group of characteristics details the residential area in which the respondents are living. 
Interestingly, rural areas had the second largest proportion of residents who experienced a decrease in average car ownership levels. The variable revealing the year that a resident's house was constructed was examined to determine what impact this had on the average car ownership level per household. The proportion of the total housing stock built after 2006 was highest in areas with a decrease in average car ownership. Areas which have shown a decrease in car ownership have a surprisingly large proportion of people $(60 \%)$ using the car as their mode of travel to work. An above average percentage of people from areas with no change in car ownership drive to work. Areas which have seen an increase in average car ownership per household have a high percentage of people walking or cycling to work. The results for the number of bus stops per 1,000 people indicate that $37 \%$ of people living in areas which experienced a decrease in car ownership levels had 11-15 bus stops per 1000 people. A higher than expected percentage of people from areas with a decrease in average car ownership had no bus stops in their ED. ED's with no change in average car ownership had an above average percentage of people with access to $16-20$ and $21+$ bus stops per 1000 people. Rail availability is $13 \%$ higher than average in areas which have shown a decrease in car ownership levels.

Table 2 Descriptive statictics

\begin{tabular}{|lllllll|l|l|}
\hline & $\begin{array}{l}\text { GDA } \\
\text { average }\end{array}$ & $\begin{array}{l}\text { Areas with } \\
\text { decrease }\end{array}$ & \multicolumn{2}{l|}{$\begin{array}{l}\text { Areas with no } \\
\text { change }\end{array}$} & \multicolumn{2}{l|}{$\begin{array}{l}\text { Areas with } \\
\text { increase }\end{array}$} \\
\hline N & $\%$ & $\mathrm{~N}$ & $\%$ & $\mathrm{~N}$ & $\%$ & $\mathrm{~N}$ & $\%$ \\
\hline $15-24$ & & & & & & & & \\
\hline $25-34$ & 49496 & 7 & 9837 & 7 & 6978 & 7 & 32681 & 7 \\
\hline $35-44$ & 214455 & 33 & 45795 & 35 & 29963 & 30 & 138697 & 33 \\
\hline $45-54$ & 176173 & 27 & 33552 & 25 & 27804 & 28 & 114817 & 27 \\
\hline
\end{tabular}




\begin{tabular}{|c|c|c|c|c|c|c|c|c|}
\hline $55+$ & 85124 & 13 & 18025 & 14 & 14296 & 14 & 52803 & 12 \\
\hline Total & 659062 & 100 & 131830 & 100 & 100600 & 100 & 426632 & 100 \\
\hline \multicolumn{9}{|l|}{ Year dwelling built } \\
\hline Not stated & 30544 & 5 & 5068 & 4 & 3590 & 4 & 21886 & 5 \\
\hline Before 1919 & 43788 & 7 & 5810 & 4 & 4401 & 4 & 33577 & 8 \\
\hline $1919-1945$ & 37253 & 6 & 4120 & 3 & 3237 & 3 & 29896 & 7 \\
\hline $1946-1960$ & 50567 & 8 & 7126 & 5 & 5752 & 6 & 37689 & 9 \\
\hline $1961-1970$ & 43751 & 7 & 10285 & 8 & 7329 & 7 & 26137 & 6 \\
\hline $1971-1980$ & 90884 & 13 & 22668 & 17 & 15666 & 16 & 52550 & 12 \\
\hline $1981-1990$ & 73287 & 11 & 11272 & 9 & 10999 & 11 & 51016 & 12 \\
\hline $1991-2000$ & 108443 & 16 & 18284 & 14 & 15859 & 15 & 74300 & 17 \\
\hline $2001-2005$ & 111123 & 16 & 22687 & 17 & 20000 & 20 & 68436 & 16 \\
\hline 2006 or later & 69422 & 11 & 24510 & 19 & 13767 & 14 & 31145 & 8 \\
\hline Total & 659062 & 100 & 131830 & 100 & 100600 & 100 & 426632 & 100 \\
\hline \multicolumn{9}{|c|}{ Mode of travel to work } \\
\hline Walk/Cycle & 105127 & 16 & 18972 & 14 & 9994 & 10 & 76161 & 18 \\
\hline Bus & 70571 & 11 & 11488 & 9 & 9074 & 9 & 50009 & 12 \\
\hline Train & 45988 & 7 & 11634 & 9 & 7141 & 7 & 27213 & 6 \\
\hline Other & 8749 & 1 & 1821 & 1 & 1398 & 1 & 5530 & 1 \\
\hline Driver & 385113 & 58 & 78600 & 60 & 65838 & 65 & 240675 & 56 \\
\hline Passenger & 23283 & 4 & 4538 & 3 & 3574 & 4 & 15171 & 4 \\
\hline $\begin{array}{l}\text { Works mainly at or } \\
\text { from home }\end{array}$ & 20231 & 3 & 4777 & 4 & 3581 & 4 & 11873 & 3 \\
\hline Total & 659062 & 100 & 131830 & 100 & 100600 & 100 & 426632 & 100 \\
\hline \multicolumn{9}{|c|}{ Bus stops per 1000 people } \\
\hline None & 32867 & 5 & 14797 & 11 & 7951 & 8 & 10119 & 2 \\
\hline $1-5$ stops & 163100 & 25 & 19470 & 15 & 28831 & 29 & 114799 & 27 \\
\hline $6-10$ stops & 198532 & 30 & 30792 & 23 & 30328 & 30 & 137412 & 33 \\
\hline $11-15$ stops & 168766 & 25 & 48493 & 37 & 11504 & 11 & 108769 & 25 \\
\hline $16-20$ stops & 50064 & 8 & 5285 & 4 & 10632 & 11 & 34147 & 8 \\
\hline $21+$ stops & 45733 & 7 & 12993 & 10 & 11354 & 11 & 21386 & 5 \\
\hline Total & 659062 & 100 & 131830 & 100 & 100600 & 100 & 426632 & 100 \\
\hline \multicolumn{9}{|l|}{ Rail availability } \\
\hline No & 460548 & 70 & 74587 & 57 & 69140 & 69 & 316821 & 74 \\
\hline Yes & 198514 & 30 & 57243 & 43 & 31460 & 31 & 109811 & 26 \\
\hline Total & 659062 & 100 & 131830 & 100 & 100600 & 100 & 426632 & 100 \\
\hline
\end{tabular}

\section{Multinomial Logistic Regression Model Results}

Table 4 details the multinomial logistic regression model for the GDA. The first set of findings relates to a worker's age and shows that individuals aged $35-54$ are much more likely to reside in areas with an increase in average car ownership. The findings demonstrate that urban areas with a population of between 20,000 and 49,999 are most likely to experience an increase in average car ownership levels. Areas with no change in average car ownership were likely in urban areas with a population between 10,000 and 19,999 people. The year in which an individual's dwelling was built showed that in EDs with an increase in average car ownership dwellings were likely to have been built before 1960. The mode of travel to work was seen to have an impact on the change in average car ownership levels in certain areas. In areas with an increase in average car ownership travel to work by bus was more likely than in areas with a decrease in average car ownership. In areas which experienced no change in 
average car ownership walking or cycling to work was less likely. The first transport variable examined the impact of the number of bus stops per 1000 people in each ED. The results show that areas with an increase in average car ownership are more likely to have 1-5 bus stops per 1000 people. EDs with a large number of bus stops (16-20 per 1000 people) were likely to have no change in average car ownership. The final variable measured the impact of rail availability within an ED. It was most likely that no rail was available in EDs which had an increase or no change in average car ownership levels.

$\underline{\text { Table } 3 \text { Multinomial logistic regression model }}$

\begin{tabular}{|lll|}
\hline Age & No change & Increase \\
\hline $15-24$ & $-.090^{*}$ & $.085^{*}$ \\
\hline $25-34$ & $-.134^{*}$ & $.094^{*}$ \\
\hline $35-44$ & $.008^{* * *}$ & $.179^{*}$ \\
\hline $45-54$ & $.037^{* * *}$ & $.128^{*}$ \\
\hline $55+$ & Ref. & Ref. \\
\hline Area type & & $.450^{*}$ \\
\hline Urban area of 0 -999 people & $.167^{*}$ & \\
\hline
\end{tabular}




\begin{tabular}{|c|c|c|}
\hline Urban area of $1,000-1,499$ people & $.559 *$ & -.238 * \\
\hline Urban area of $1,500-1,999$ people & $1.475^{*}$ & $.405 *$ \\
\hline Urban area of $2,000-4,999$ people & $-.340 *$ & .335 * \\
\hline Urban area of $5,000-9,999$ people & 1.096 * & $.778 *$ \\
\hline Urban area of $10,000-19,999$ people & 2.408 * & 1.253 * \\
\hline Urban area of $20,000-49,999$ people & 1.558 * & 3.334 * \\
\hline Urban area of $1,000,000$ people or more & $.283^{*}$ & $1.107^{*}$ \\
\hline Rural area & Ref. & Ref. \\
\hline \multicolumn{3}{|l|}{ Year dwelling built } \\
\hline Not stated & $.327^{*}$ & 1.062 * \\
\hline Before 1919 & $.581 *$ & 1.648 * \\
\hline $1919-1945$ & $.575^{*}$ & 1.786 * \\
\hline $1946-1960$ & $.468 *$ & 1.357 * \\
\hline $1961-1970$ & $.287^{*}$ & $.554 *$ \\
\hline $1971-1980$ & $.179 *$ & $.484^{*}$ \\
\hline $1981-1990$ & $.505^{*}$ & 1.226 * \\
\hline $1991-2000$ & .263 * & .968 * \\
\hline $2001-2005$ & $.308 *$ & .764 * \\
\hline 2006 or later & Ref. & Ref. \\
\hline \multicolumn{3}{|l|}{ Mode of travel to work } \\
\hline Walk/Cycle & -.274 * & $.141^{*}$ \\
\hline Bus & $.076^{* *}$ & $.208^{*}$ \\
\hline Train & $-.049 * * *$ & -.084 * \\
\hline Other & $.060^{* \star * \star}$ & $.137^{*}$ \\
\hline Driver & $.045^{* *}$ & $.067^{* *}$ \\
\hline Passenger & $-.058^{* *}$ & .068 ** \\
\hline Works from home & Ref. & Ref. \\
\hline \multicolumn{3}{|l|}{ Bus stops per 1000 people } \\
\hline None & $-.816 *$ & -.394 * \\
\hline 1 - 5 stops & $.103^{*}$ & $1.313^{*}$ \\
\hline $6-10$ stops & $-.553^{*}$ & $.807^{*}$ \\
\hline $11-15$ stops & -1.578 * & $.166 *$ \\
\hline $16-20$ stops & $.490 *$ & 1.108 * \\
\hline $21+$ stops & Ref. & Ref. \\
\hline \multicolumn{3}{|l|}{ Rail availability } \\
\hline No & $.914^{*}$ & $.871^{*}$ \\
\hline Yes & Ref. & Ref. \\
\hline Number of cases & 659,062 & \\
\hline R-squared & 0.27 & \\
\hline -2 Log Likelihood & 167321 & \\
\hline
\end{tabular}

*Significant at $1 \%$

** Significant at $5 \%$

*** Significant at $10 \%$

$* * * *$ Not significant

\section{Conclusions}

The results of this study give a clear indication of the characteristics of households in EDs which experienced a change in average car ownership over the study period. The results highlight how the age of the head of the household, the year the residences 
they live in was built and the mode of transport to work impacted on the change in average car ownership. Furthermore, characteristics related to the ED where households are situated including rail availability, number of bus stops per 1000 people and the density of the area proved informative in predicting whether an increase, decrease or no change in average car ownership was experienced.

Older workers were likely to be living in areas with an increase in average car ownership in the GDA. In addition, living in dwellings built before 1960 were more likely to have an increase in average car ownership as were those living in the second most densely populated EDs in all study areas. This cohort of the working population could be targeted to reduce their average car ownership levels.

Examining the mode of travel to work suggests that travel by bus has been an ineffective means of reducing average car ownership levels in the GDA. The results revealed the high likelihood that people from areas that experienced an increase in average car ownership travel by bus to work. Accordingly, current measures being taken to improve bus services should be re-valuated to consider whether they have an impact on car ownership levels.

The finding that 1-5 bus stops per 1000 people is likely in areas with an increase in average car ownership in the GDA, implies that this is not an adequate number for reducing average car ownership levels. It must be noted however that this variable does not give a reliable indication of the level of service in operation in specific EDs. As a result, the impact of the number of bus stops per 1000 people on average car ownership levels is still unclear. The availability of rail within an ED was likely to result in a reduction in car ownership over the study period. This is particularly apparent in EDs where new rail services were introduced over the study period. This impact of rail suggests that there is scope for policy intervention in the future to motivate people to reduce their car ownership.

These results need to be considered in the context of the economic recession which Ireland has experienced since 2008. In real terms, employment levels dropped (CSO 2012c) as did the number of new cars being registered. Since the study only focused on car ownership among the employed the average car ownership levels may have been affected.

\section{Acknowledgments}

The authors would like to thank the Central Statistics Office of Ireland for providing the data for this study.

\section{References}

Bhat, C. R., Guo, J. Y. A comprehensive analysis of built environment characteristics on household residential choice and auto ownership levels. Transportation Research Part B: Methodological, 41, 2007, 506-526.

Caulfield, B. An examination of the factors that impact upon multiple vehicle ownership: The case of Dublin, Ireland, Transport Policy, 19, 2012, p132 - 138

Caulfield., B. Re-cycling a city - examining the growth of cycling in Dublin, Transportation Research Part A: Policy and Practice, 61, 2014, p216 - 226

Caulfield, B., Ahern, A., The Green Fields of Ireland: The Legacy of Dublin's Housing Boom and the Impact on Commuting, Case Studies on Transport Policy, 2, (1), 2014, p20 - 27 
Chiou, Y.-C., Wen, C.H., Tsai, S.H., Wang, W.Y. Integrated modeling of car/motorcycle ownership, type and usage for estimating energy consumption and emissions. Transportation Research Part A: Policy and Practice, 43, 2009 665-684.

Clark, S. D. Characterising and predicting car ownership using rough sets. Transportation Research Part C: Emerging Technologies, 17, 2009a. 381-393.

CSO 2012a. Census 2011 Profile 4 The roof over our heads. Central Statiscitcs Office, Dublin, Ireland.

CSO 2012b. Census 2011 Profile 10 Door to door. Central Statiscitcs Office, Dublin, Ireland.

CSO. 2012c. Press Release This is Ireland-Highlights from Census 2011, Part 2 [Online]. Available: http://www.cso.ie/en/newsandevents/pressreleases/2012pressreleases/pressreleasethisi sireland-highlightsfromcensus2011part2/ [Accessed 18th November 2012 2012].

CSO 2011. 2011 Census of population interactive tables.

Dargay, J., Gately, D. Income's effect on car and vehicle ownership, worldwide: 1960-2015. Transportation Research Part A: Policy and Practice, 33, 1999, 101-138.

Delbosc, A. Household composition and within-household car saturation in Melbourne. Transport Policy, 25, 2013, 94-100.

Forfas Ireland. Sharing our future : Ireland 2025 : strategic policy requirements for enterprise development, 2009, Dublin, Forfas.

Giuliano, G. \& Dargay, J. Car ownership, travel and land use: a comparison of the US and Great Britain. Transportation Research Part A: Policy and Practice, 40, 2006, 106-124.

Hennessy, H., Tol, R. S. J. The Impact of Government Policy on Private Car Ownership in Ireland. Economic \& Social Review, 42, 2011, 135-157.

Kim, H. S., Kim, E. Effects of Public Transit on Automobile Ownership and Use in Households of the USA. Review of Urban and Regional Development Studies, 16, 2004, 245-262.

Morgenroth, E. 2002. Commuting in Ireland: An Analysis of Inter-County Commuting Flows, ESRI, Dublin.

National Transport Authority. Greater Dublin Area draft transport strategy 20112030 vision. 2007. Dublin, Ireland

Nutley, S. Monitoring rural travel behaviour: a longitudinal study in Northern Ireland 1979-2001. Journal of Transport Geography, 13, 2005, 247-263. 
Pongthanaisawan, J., Sorapipatana, C. Relationship between level of economic development and motorcycle and car ownerships and their impacts on fuel consumption and greenhouse gas emission in Thailand. Renewable and Sustainable Energy Reviews, 14, 2010, 2966-2975.

Ritter, N., Vance, C. Do fewer people mean fewer cars? Population decline and car ownership in Germany. Transportation Research Part A: Policy and Practice, 50, 2013, 74-85.

Whelan, G. 2007. Modelling car ownership in Great Britain. Transportation Research Part A: Policy and Practice, 41, 205-219. 
Reviewer \#1: Adding info about evolution of car ownership in Ireland is useful. Literature review is sufficient, not comprehensive and could develop a theme, rather than the sequel of short summaries. Paper is well organized and wellwritten.

Response: Thank you for the kind comments. We have revised the literature review to fit in with the comments from both reviewers.

My major concern is the very simple analysis that does not do any justice to the nature of the data and dynamics. The analyses should be replaced with advances econometrics analysis.

Response: This was considered during the research, but the focus of the paper is to look at the policy in relation to car ownership and not advances in econometric analysis.

Reviewer \#2: The paper addresses an interesting topic and it is well written and structured.

There are two weak points. The literature review should be more comprehensive and better digested. Not only the description of summaries.

Response: We have revised the literature review to fit in with the comments from both reviewers.

Also the analysis is very simplified for the potential of the available data. The author should reflect on the possibility of upgrading the analysis

Response: This was considered during the research, but the focus of the paper is to look at the policy in relation to car ownership and not advances in econometric analysis. 
Research Highlights

- The case study shows the changing trends of car ownership over the recession period in Dublin.

- The research shows the factors which impact on car ownership.

- A detailed case study on the ways to measure car ownership. 